\title{
Evaluasi Penerimaan dan Kelanjutan Penggunaan Sistem Informasi Kearsipan Inaktif (SIKI) oleh Unit Kerja di Lingkungan Universitas Gadjah Mada
}

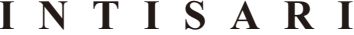

Salah satu upaya terlaksananya penyelenggaraan kearsipan di Universitas Gadjah Mada (UGM) adalah dengan penggunaan teknologi informasi, salah satunya adalah penggunaan sistem informasi kearsipan untuk arsip inaktif. Penelitian ini termotivasi untuk menganalisis evaluasi penerimaan dan kelanjutan penggunaan Sistem Informasi Kearsipan Inaktif (SIKI) di lingkungan UGM. Technology Acceptance Model (TAM) Venkatesh dan Davis digunakan sebagai dasar penelitian. Model ini dipilih karena merupakan sebuah konsep yang dianggap paling baik dalam menjelaskan perilaku user (pengguna) terhadap sistem teknologi informasi baru. Selanjutnya studi ini memodifikasi teori yang mempengaruhi attitude toward using yaitu ignorance dan multidimensional committment. Terdapat lima konstruk sebagai pembentuk ignorance dan multidimensional committment yaitu complexity, power of distance, incentive fairness, identification, dan internalization. Data penelitian diperoleh melalui sembilan key informan yaitu yaitu administrator SIKI unit kerja di lingkungan UGM yang pernah mengikuti sosialisasi SIKI oleh Arsip UGM. Hasil penelitian yang diperoleh adalah tidak hanya complexity, power of distance, incentive fairness, identification, dan internalization saja yang berpengaruh pada penerimaan suatu sistem informasi dalam hal ini adalah penerimaan SIKI, namun terdapat faktor lain yang mempengaruhi kelanjutan penggunaan SIKI yaitu kebijakan pimpinan terkait penggunaan SIKI.

\section{$\begin{array}{lllllllll}A & B & S & T & R & A & C & T\end{array}$}

One of the efforts to implement archiving at Universitas Gadjah Mada (UGM) is the use of information technology, one of which is the use of archival information systems for inactive records. This study was motivated to analyze the evaluation of the acceptance and continuation of the use of the Sistem Informasi Kearsipan Inaktif (SIKI) at UGM. Venkatesh
PENULIS

Ully Isnaeni Effendi

Sumiyana

Ida Fajar Priyanto

Program Studi

Magister Manajemen

Pendidikan Tinggi UGM

Universitas Gadjah Mada

ullyeffendi@ugm.ac.id

KATA KUNCI

arsip inaktif, sistem informasi

kearsipan, Technology

Acceptance Model (TAM)

\section{KEY WORDS}

archival information system, inactive records, Technology Acceptance Model (TAM) 
and Davis's Technology Acceptance Model (TAM) was used as the basis of the research. This model was chosen because it is a concept that is considered the best in explaining the behavior of users (users) of new information technology systems. Furthermore, this study modifies the theory that influences attitudes toward using, namely ignorance and multidimensional commitment. There are five constructs as a form of multidimensional committment and ignorance, namely complexity, power of distance, incentive fairness, identification, and internalization. The research data was obtained through nine key informants, namely the SIKI administrator at the UGM work unit who had attended SIKI socialization by Arsip UGM. The results of the research are not only complexity, power of distance, incentive fairness, identification, and internalization which affect the acceptance of an information system in this case is the acceptance of SIKI, but there are other factors that influence the continued use of SIKI, namely the leadership policy regarding the use of SIKI.

\section{PENGANTAR}

\section{Latar Belakang Masalah}

Arsip Universitas Gadjah Mada (UGM) sebagai salah satu unit kerja di UGM turut mendukung dalam pencapaian kinerja organisasi atau UGM. Arsip UGM adalah salah satu lembaga kearsipan perguruan tinggi yang berbentuk satuan organisasi perguruan tinggi, baik negeri maupun swasta yang melaksanakan fungsi dan tugas penyelenggaraan kearsipan di lingkungan perguruan tinggi (UndangUndang Republik Indonesia Nomor 43 Tahun 2009). Penyelenggaraan kearsipan yang dimaksud adalah keseluruhan kegiatan yang meliputi kebijakan, pembinaan kearsipan, dan pengelolaan arsip dalam suatu sistem kearsipan nasional didukung dengan sumber daya manusia, prasarana dan sarana, dan sumber daya lainnya. Arsip Universitas atau University Archives adalah sebuah program yang terkait dengan kebijakan, sumber daya manusia, khazanah arsip yang dimiliki, dan fasilitas gedung untuk melestarikan dan membuat agar warisan dokumenter dari suatu lembaga pendidikan tinggi dapat diakses. Dokumen-dokumen tersebut adalah dokumen terpilih dan dikelola secara sistematis berdasarkan teori kearsipan dan teknis pengelolaan arsip (Maher, 1992:16). Khazanah arsip yang dimiliki dan dilayankan oleh Arsip UGM adalah arsip statis, yaitu arsip yang dihasilkan oleh pencipta arsip karena memiliki nilai 
guna kesejarahan, telah habis retensinya, dan berketerangan dipermanenkan yang telah diverifikasi baik secara langsung maupun tidak langsung oleh Arsip Nasional Republik Indonesia (ANRI) dan/ atau lembaga kearsipan.

Selain arsip statis, Arsip UGM juga melaksanakan pengelolaan arsip inaktif dan pengembangan records center, serta pengembangan teknologi informasi kearsipan. Salah satu upaya terlaksananya penyelenggaraan kearsipan di UGM adalah dengan penggunaan teknologi informasi, antara lain penggunaan sistem informasi kearsipan untuk arsip inaktif. Keberlangsungan sistem informasi kearsipan untuk arsip inaktif yaitu Sistem Informasi Kearsipan Inaktif (SIKI) penting bagi terintegrasinya kearsipan inaktif di seluruh unit kerja di lingkungan UGM. Berdasarkan bagan organisasi kearsipan di lingkungan perguruan tinggi, dapat dilihat bahwa arsip inaktif yang ada di UGM tersebar di unit kearsipan II seperti fakultas, direktorat, pusat studi, sekolah, unit pelaksna teknis (UPT), dll, untuk arsip inaktif dengan masa retensi kurang dari 10 (sepuluh) tahun. Selanjutnya berada di unit kearsipan I seperti lembaga kearsipan perguruan tinggi untuk arsip dengan masa retensi 10 tahun atau lebih, dalam hal ini Arsip UGM.

SIKI membantu dalam proses manajemen arsip dinamis inaktif. Manajemen arsip inaktif merupakan kegiatan pengelolaan arsip yang masih memiliki nilai guna tetapi frekuensi penggunaannya sudah menurun. Kegiatan ini menjadi salah satu tugas dari seluruh unit kerja di lingkungan UGM. Arsip inaktif pada umumnya memiliki volume lebih banyak jika dibandingkan dengan arsip aktif atau statis. Volume arsip inaktif yang besar mengakibatkan seringnya muncul masalah kearsipan di unit kerja. Masalah tersebut antara lain adalah terjadi penumpukan arsip, sulitnya penemuan kembali arsip, penemuan kembali arsip membutuhkan waktu yang lama, kemungkinan terjadi hilangnya arsip, kebutuhan ruang simpan yang tidak sebanding dengan volume arsip, serta tidak berjalannya penyusutan arsip dengan baik. Hal ini apabila dibiarkan akan membawa dampak negatif bagi unit kerja serta UGM. Arsip yang tidak teratur di unit kerja akan menghambat proses akuisisi atau penyerahan arsip statis bernilai guna sejarah bagi UGM yang berasal dari unit kerja ke lembaga kearsipan yaitu Arsip UGM. Oleh karena itu, manajemen arsip inaktif menjadi bagian penting pada kegiatan manajemen kearsipan di setiap unit kerja. SIKI dirancang sebagai upaya terselenggaranya otomasi manajemen arsip inaktif diharapkan mampu memberikan solusi dari permasalahan yang ada di unit kerja di lingkungan UGM.

Arsip UGM sebagai lembaga kearsipan perguruan tinggi selaku 
pembina kearsipan di UGM telah mengembangkan SIKI sejak tahun 2014. SIKI telah disosialisasikan kepada unit kerja di lingkungan UGM sebanyak tiga kali pada tahun 2014 dan 2018. Berdasarkan data yang ada di Arsip UGM, sampai dengan saat ini baru digunakan oleh beberapa unit kerja yang ada di lingkungan UGM. Oleh karena itu, berdasarkan alasan di atas, penulis ingin mengkaji lebih dalam mengenai evaluasi penerimaan pengguna SIKI pada unit kerja di lingkungan UGM dengan menggunakan 5 aspek yang diadopsi dari teori Technology Acceptance Model (TAM).

Penelitian ini termotivasi untuk menganalisis evaluasi penerimaan SIKI dengan menggunakan TAM. Perilaku pengguna yang menolak penggunaan sistem teknologi informasi sebagai salah satu solusi penyelesaian masalah organisasi menjadi salah satu alasan tingkat penggunaan sistem informasi yang rendah. Perilaku tersebut terbentuk dari sikap dan persepsi pengguna terhadap sistem teknologi informasi tersebut. Penelitian Davis et al. (1989:985) menyatakan bahwa adanya manfaat yang dirasakan (dipersepsikan) dan kemudahan dalam penggunaan yang dirasakan oleh pengguna sistem informasi akan meningkatkan minat dalam penggunaannya. Model tersebut menganggap penggunaan sistem informasi dipengaruhi oleh minat (intention) pemanfaatan sistem informasi. Minat (intention) pemanfaatan sistem informasi tersebut dipengaruhi dua keyakinan individual yaitu persepsi tentang teknologi kegunaan yang dirasakan (perceived usefulness) dan persepsi tentang kemudahan penggunaan teknologi yang dirasakan (perceived ease of use) merupakan determinan penting dari penggunaan teknologi informasi. Tujuan utama TAM menurut Davis (1989:983), adalah memberikan dasar penelusuran pengaruh aspek perilaku individu berupa persepsi, sikap dan minat dalam penggunaan sistem. TAM dianggap sebagai model penelitian perilaku yang paling luas digunakan dalam penelitian adopsi sistem teknologi informasi. TAM merupakan model yang populer dan banyak digunakan dalam berbagai penelitian mengenai adopsi sistem teknologi informasi. TAM juga menyatakan bahwa dampak variabelvariabel eksternal seperti (karakteristik sistem, proses pengembangan dan pelatihan) terhadap intention to use adalah dimediasi oleh perceived of usefulness dan perceived ease of use. Konsep TAM juga menyatakan bahwa perceived usefulness dipengaruhi oleh perceived ease of use.

\section{Rumusan Masalah \\ Rumusan masalah dalam penelitian ini yaitu: 1) Bagaimana penerimaan SIKI di unit kerja di}


lingkungan UGM; 2) Apakah SIKI diterima di unit kerja di lingkungan UGM;

3) Bagaimana penerimaan penggunaan SIKI di unit kerja di lingkungan UGM; dan 4) Bagaiamana strategi kebijakan yang harus dilakukan.

\section{Tujuan Penelitian}

Adapun tujuan dari penelitian ini yaitu: 1) Untuk mengidentifikasi penerimaan SIKI di unit kerja di lingkungan UGM; 2) Untuk mengevaluasi penerimaan SIKI di unit kerja di lingkungan UGM; 3) Untuk mengetahui penerimaan penggunaan SIKI di unit kerja di lingkungan UGM; dan 4) Untuk mengetahui langkah strategi kebijakan yang harus dilakukan untuk mengoptimalkan tingkat pemanfaatan dan penggunaan SIKI.

\section{Metodologi Penelitian}

Penelitian ini menggunakan pendekatan studi kasus sebagai bagian dari penelitian deskriptif kualitatif. Sebagaimana pendapat Creswell (2009:20) yaitu metodologi kualitatif dapat dilakukan dengan berbagai pendekatan antara lain penelitian partisipatoris, analisis wacana, etnografi, grounded theory, studi kasus, fenomenologi, dan naratif. Studi kasus merupakan strategi penelitian dimana di dalamnya peneliti menyelidiki secara cermat suatu program, peristiwa, aktivitas, proses, atau sekelompok individu (Creswell, 2009:20). Oleh sebab itu, penelitian ini dimaksudkan untuk mengungkap fakta-fakta yang yang terdapat pada setiap unit kerja yang menggunakan SIKI, dimana pendapatnya dapat dipertanggungjawabkan secara ilmiah yang kemudian dideskripsikan dengan berpedoman pada butir-butir pertanyaan dalam wawancara di lapangan. Setelah data-data terkumpul kemudian disajikan dalam bentuk kata-kata atau kalimat yang sesuai dengan kenyataan yang ada.

Lokasi penelitian ini adalah unit kerja di lingkungan UGM melalui pengelola arsip, petugas arsip, atau arsiparis sebagai administrator SIKI unit kerja. Penentuan sampel dalam penelitian ini dilakukan dengan Purposive Sampling. Purposive Sampling adalah salah satu teknik sampling non random sampling dimana peneliti menentukan pengambilan sampel dengan cara menetapkan ciri-ciri khusus yang sesuai dengan tujuan penelitian sehingga diharapkan dapat menjawab permasalahan penelitian. Populasi dalam penelitian ini adalah semua unit kerja yang mengikuti sosialisasi SIKI oleh Arsip UGM pada tanggal 12 September 2018 dan workshop tanggal 19-20 Oktober 2018. Sampel atau narasumber yang akan diambil dalam penelitian ini yang dijadikan sebagai informan adalah keterwakilan dari unit 
kerja di lingkungan UGM yang menggunakan SIKI dengan kriteria tertentu dan berdasarkan klaster keilmuan di UGM. Dengan pertimbangan bahwa informan adalah orang dalam unit kerja yang benar-benar mengetahui atau terlibat langsung dengan fokus penelitian yang akan diteliti di unit kerja yang telah menggunakan SIKI sehingga secara langsung telah menggunakan sistem informasi tersebut. Dalam pengumpulan data, informan penelitian adalah orangorang yang dipandang mampu memberikan informasi selengkaplengkapnya dan berkaitan dengan bidang yang diteliti, sehingga data yang diperoleh dapat diakui kebenarannya.

Informan penelitian ini yaitu administrator SIKI unit kerja yaitu pengelola arsip, petugas arsip, atau arsiparis yang ditunjuk oleh unit kerja yang bersangkutan. Pembagian sampel penelitian yang dapat dilakukan adalah:

1. Unit kerja berdasarkan klaster keilmuan di UGM, yaitu:

a. Klaster Teknik: Fakultas Teknik;

b. Klaster Kesehatan (Fakultas Kedokteran, Kesehatan Masyarakat, dan Keperawatan, Fakultas Kedokteran Gigi, dan Fakultas Farmasi): Fakultas Kedokteran Gigi;

c. Klaster Agro (Fakultas Kedokteran Hewan, Fakultas
Kehutanan, Fakultas Pertanian, Fakultas Teknologi Pertanian, dan Fakultas Peternakan): Fakultas Peternakan;

d. Klaster Sosio-Humaniora (Fakultas ISIPOL, Fakultas Filsafat, Fakultas Ekonomika dan Bisnis, Fakultas Ilmu Budaya, Fakultas Hukum, dan Fakultas Psikologi): Fakultas Ekonomika dan Bisnis;

e. Klaster Sains (Fakultas Biologi, Fakultas Geografi, dan Fakultas MIPA): Fakultas MIPA; dan

f. K laster Vokas i dan Pascasarjana (Sekolah Vokasi dan Sekolah Pascasarjana): Sekolah Pascasarjana.

2. Unit kerja selain klaster keilmuan di UGM, yaitu Direktorat Aset.

3. Unit kerja Arsip UGM.

Berdasarkan data tersebut diperoleh 9 informan pada 9 unit kerja di lingkungan UGM yang berperan sebagai administrator SIKI dan pernah mengikuti sosialisasi SIKI yang dilakukan oleh Arsip UGM(tebel 1).

Penelitian ini merupakan penelitian kualitatif atau penelitian lapangan, maka analisis data selama di lapangan dilakukan pada saat pengumpulan data berlangsung dan setelah selesai pengumpulan data yang 
Tabel 1

Daftar Informan Penelitian

\begin{tabular}{|c|c|c|}
\hline No & $\begin{array}{c}\text { Kode } \\
\text { Informan }\end{array}$ & $\begin{array}{c}\text { Pendidikan } \\
\text { Terakhir }\end{array}$ \\
\hline 1 & KI 1 & S1 Manajemen \\
\hline 2 & KI 2 & D III Kearsipan \\
\hline 3 & KI 3 & D III Kearsipan \\
\hline 4 & KI 4 & D III Kearsipan \\
\hline 5 & KI 5 & $\begin{array}{l}\text { S1 Ilmu Sosial } \\
\text { dan Politik }\end{array}$ \\
\hline 6 & KI 6 & D III Kearsipan \\
\hline 7 & KI 7 & SLTA \\
\hline 8 & KI 8 & D IV Kearsipan \\
\hline 9 & KI 9 & $\begin{array}{l}\text { S1 Ilmu } \\
\text { Komputer }\end{array}$ \\
\hline
\end{tabular}

Sumber: Data diolah, 2019

dilakukan dalam periode tertentu. Tahap atau fase utama analisis data dalam teknik analisis kualitatif model Miles dan Huberman (1994:12) terdiri dari pengumpulan data, reduksi data, penyajian data, dan menarik kesimpulan atau verifikasi.

Instrumen penelitian ini yang utama adalah peneliti itu sendiri. Peneliti melakukan sendiri pengamatan atau observasi dan wawancara mendalam untuk mendapatkan informasi yang akurat. Pedoman wawancara dan pedoman observasi merupakan kelengkapan penunjang dan kedudukannya sebagai alat pendukung yang selalu disesuaikan dengan kebutuhan yang dihadapi di lapangan oleh peneliti sebagai instrumen penelitiannya.

Jenis data yang digunakan dalam penelitian ini ada dua jenis yaitu data primer dan data sekunder:

a. Data primer adalah data yang langsung dikumpulkan atau diperoleh dari sumber pertama. Data primer dalam hal ini diperoleh berdasarkan wawancara yang dilakukan terhadap pimpinan unit kerja atau pengguna yang berasal dari pejabat yang ditunjuk oleh unit kerja yang bersangkutan dan administrator unit kerja yaitu pengelola arsip atau arsiparis yang ditunjuk oleh unit kerja yang bersangkutan pada unit kerja di lingkungan UGM yang menggunakan SIKI.

b. Data sekunder adalah data yang tidak langsung diperoleh melalui sumber pertama, dan telah tersusun dalam bentuk dokumendokumen tertulis.

Dalam hal ini, data sekunder diperoleh melalui:

1. Dokumen dan data unit kerja, seperti gambaran umum unit kerja, peraturan, manual prosedur, dll;

2. Bahan literatur seperti buku, jurnal, dan internet sebagai bahan referensi; dan

3. Hasil penelitian terdahulu yang 
berkaitan dengan evaluasi sistem informasi dan TAM oleh peneliti sebelumnya yang masih relevan untuk digunakan sebagai bahan pertimbangan dan perbandingan.

\section{Kerangka Pemikiran}

Evaluasi adalah proses penilaian yang sistematis mencakup pemberian nilai, atribut, apresiasi dan pengenalan permasalahan serta pemberian solusisolusi atas permasalahan yang ditemukan. Selain itu evaluasi adalah kegiatan yang terencana untuk mengetahui keadaan suatu obyek dengan menggunakan instrumen dan hasilnya dibandingkan dengan tolok ukur tertentu untuk memperoleh kesimpulan. Berdasarkan pengertian di atas, maka dapat disimpulkan bahwa evaluasi adalah suatu kegiatan terencana untuk menilai suatu permasalahan yang terjadi dengan menggunakan instrumen dan hasilnya dapat dibandingkan dengan tolok ukur guna memperoleh kesimpulan dan solusi atas permasalahan yang dinilai.

Sistem informasi berarti sistem yang dapat menghasilkan informasi yang berguna. Sistem dapat diartikan sebagai kumpulan dari komponen yang saling berhubungan satu dengan yang lainnya membentuk satu kesatuan untuk mencapai tujuan tertentu (McLeod dan Schell, 2008:9). Kumpulan elemen-elemen yang saling berkaitan dan bertanggung jawab tersebut memproses masukan (input) sehingga menghasilkan keluaran (output). Sistem informasi adalah suatu kombinasi teratur apapun dari orang, perangkat keras, piranti lunak, jaringan komunikasi, dan basis data yang mengumpulkan, mengubah, dan menyebarkan informasi di dalam suatu bentuk organisasi (O'Brien, 2005:5). Sistem informasi merupakan sistem yang berada pada organisasi yang didalamnya terdapat sekelompok orang, teknologi, media, fasilitas, prosedur, dan pengendalian yang digunakan untuk tujuan mendapatkan jalur komunikasi, memproses transaksi secara rutin, memberi sinyal kepada manajemen mengenai kejadian-kejadian internal dan eksternal dan menyediakan informasi yang dapat digunakan sebagai pengambilan keputusan.

Setiap individu mempunyai tingkat penerimaan teknologi yang berbeda-beda. Persepsi mengenai teknologi berawal dari proses kognitif dan keyakinan mengenai teknologi. Model TAM sebagaimana diajukan oleh Fred D Davis telah mendominasi literaturliteratur sistem informasi. Model dalam TAM dipengaruhi oleh keyakinan individu mengenai manfaat teknologi. Penerimaan pengguna terhadap teknologi sistem informasi dapat didefinisikan sebagai kemauan yang nampak didalam kelompok pengguna untuk menerapkan teknologi sistem informasi tersebut dalam 
pekerjaannya. Semakin menerima teknologi sistem informasi yang baru, semakin besar kemauan pengguna untuk merubah praktek yang sudah ada dalam penggunaan waktu serta usaha untuk memulai secara nyata pada teknologi sistem informasi yang baru. Tetapi jika pengguna tidak mau menerima teknologi sistem informasi yang baru, maka perubahan sistem tersebut menyebabkan tidak memberikan keuntungan bagi organisasi.

Keberhasilan sistem informasi ditentukan dari berbagai faktor, yaitu proses (input menghasilkan output) sistem informasi itu sendiri dan kesesuaian dengan lingkungan pekerjaan. Sistem informasi akan berjalan dengan baik apabila pengguna atau pemakai sistem informasi tersebut juga menerima dan mau menggunakannya. Partisipasi pengguna telah lama dianggap sebagai variabel kunci dalam keberhasilan pengembangan sistem informasi (Hartwick, 1994:75). Perkembangan sistem teknologi informasi telah mengubah cara bekerja dan yang dikerjakan. Sistem informasi berfungsi sebagai alat bantu mencapai tujuan organisasi melalui penyediaan informasi untuk berbagai kegiatan organisasi. Dalam proses penerapan sistem teknologi informasi dalam pekerjaan sehari-hari, setiap individu mernpunyai persepsi yang berbeda-beda. Model penerimaan teknologi telah menggabungkan sikap (attitude) pengguna di tempat kerja dengan yang dilakukan. Prediksi jangka panjang tentang penerimaan sistem teknologi oleh pengguna dapat dilakukan dengan cara mengukur respon affective dari penggunaan teknologi baru. Davis et al. (1986:985) telah mengembangkan model yang menjelaskan perilaku individu dalam penerimaan teknologi informasi yang dinamakan TAM.

Technology Acceptance Model (TAM) diperkenalkan pertama kali oleh Fred D. Davis pada tahun 1986. TAM merupakan adaptasi dari Theory of Reasoned Action Model (TRA) yang secara khusus telah disesuaikan dengan model penerimaan sistem informasi oleh pengguna (Davis et al., 1989:985). TAM adalah teori sistem informasi yang membuat model mengenai bagaimana pengguna mau menerima dan menggunakan teknologi. TAM memberikan dasar untuk penelusuran pengaruh faktor eksternal terhadap kepercayaan, sikap, dan tujuan pengguna sistem teknologi informasi. TAM dikembangkan sehubungan dengan perilaku seseorang untuk menerima atau menolak penggunaan teknologi informasi. TAM memiliki dua sisi sebagai pengaruh utama untuk melihat perilaku penerimaan teknologi informasi yaitu sisi pertama atau yang biasa disebut beliefs yang terdiri atas perceived usefulness dan perceived ease of use dan sisi yang kedua terdiri dari 
attitude, behavior intention to use dan usage behavior (Straub, Limayen, Evaristo, 1995:1331). Gambar 1 menunjukkan tentang TAM, TAM menjelaskan hubungan antara keyakinan/
SIKI merupakan sebuah sistem yang dirancang untuk mendorong terselenggaranya otomasi manajemen arsip inaktif di Arsip UGM, yang ke depan dapat dikembangkan dan diterapkan di

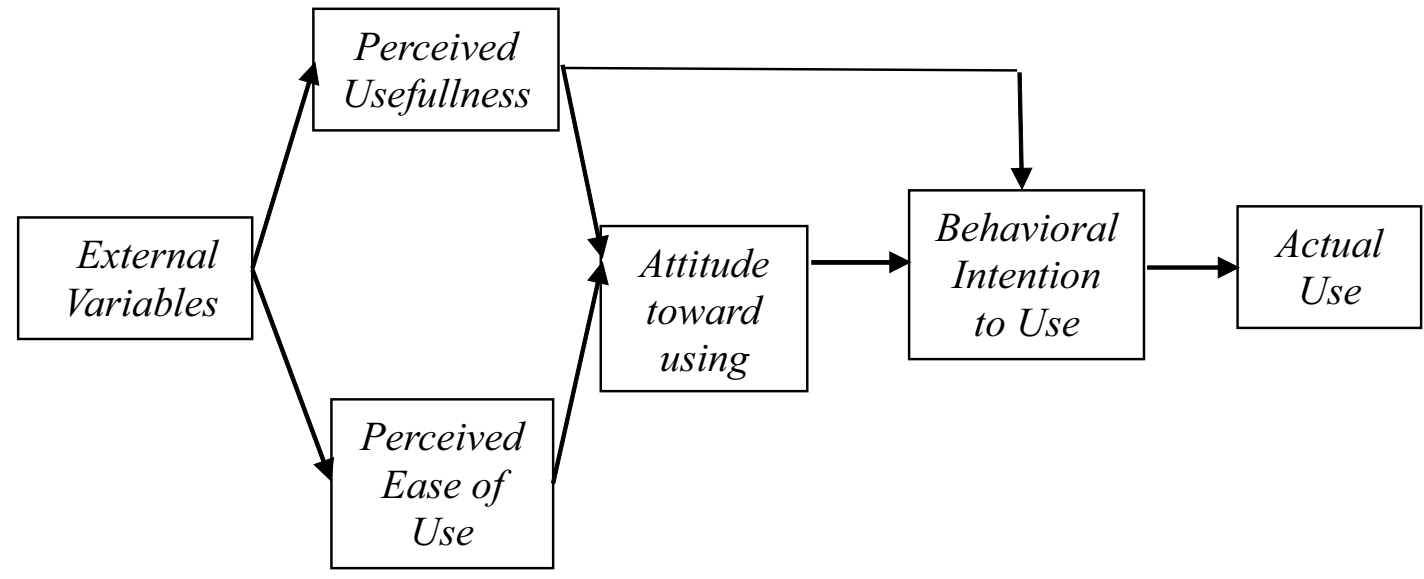

Gambar 1

Hubungan antar komponen dalam Technology Acceptance Model (TAM) Sumber: Davis, 1986:985

beliefs (usefulness dan ease of use) dengan sikap attitude, tujuan lintentions pengguna, serta penggunaan nyata dari sistem. Perceived usefulness didefinisikan oleh Davis et al. (1989:320) sebagai suatu tingkat dimana seseorang percaya bahwa penggunaan sistem secara khusus akan meningkatkan kinerjanya. Sedangkan perceived ease of use didefinisikan sebagai suatu tingkat dimana seseorang percaya bahwa penggunaan sistem secara khusus akan mengarah pada suatu usaha. Studi analisa Sun, Heshan dan Zhang, Ping (2006:59) juga pada 54 artikel jurnal diperoleh hasil construct berbeda-beda dan beberapa hubungan utama hasilnya tidak konsisten. seluruh unit kerja di lingkungan UGM. Perlu diketahui sebelumnya bahwa arsip inaktif menurut Undang-Undang Nomor 43 Tahun 2009 tentang Kearsipan adalah arsip yang frekuensi penggunaannya telah menurun. Menurut American Records Manager Association, arsip inaktif adalah arsip yang dalam satu tahun digunakan kurang dari 10 (sepuluh) kali. Sedangkan menurut International Council on Archives, arsip inaktif adalah arsip yang dalam satu tahun digunakan kurang dari 56 (lima sampai enam) kali. Arsip aktif berada di unit pengolah yaitu jurusan, bagian, bidang, seksi, dll yang berada di pencipta arsip. Sedangkan arsip inaktif berada di unit kearsipan dua yaitu 
fakultas, biro, UPT, direktorat, dll untuk arsip inaktif yang mempunyai retensi atau umur arsip kurang dari 10 (sepuluh) tahun. Untuk arsip inaktif yang mempunyai retensi atau umur arsip lebih dari atau sama dengan 10 (sepuluh) tahun berada di unit kearsipan satu yaitu di universitas. Alur atau proses perpindahan tersebut melalui kegiatan penyusutan arsip.

Salah satu tujuan utama pembuatan sistem ini adalah sebagai sarana temu kembali arsip inaktif yang cepat dan andal. Pencarian arsip dapat dilakukan dengan menggunakan kata kunci yang dapat ditelusuri dari deskripsi arsip, tahun arsip serta entitas atau pokok masalah arsip. SIKI mempunyai berbagai fitur untuk membantu manajemen arsip inaktif yang secara garis besar dirancang berfungsi untuk:

a. integrasi database arsip inaktif UGM;

b. menydiakan sarana bantu penemuan kembali/ finding aids arsip inaktif UGM; dan

c. otomasi penyusutan arsip inaktif berdasarkan retensi.

SIKI ini hanya dapat diakses oleh pengguna di lingkungan UGM, yaitu pimpinan unit pencipta arsip dan arsiparis/ petugas pengelola arsip di Arsip UGM dan di unit kerja sebagai administrator yang telah ditunjuk sebelumnya. Adanya program SIKI diharapkan mampu memberikan solusi dari permasalahan- permasalahan yang ada pada manajemen arsip inaktif yang ada di lingkungan UGM.

Sistem informasi kearsipan inaktif ini merupakan sistem informasi berbasis web yang menggunakan:

1. Back End: PHP Framework

CodeIgniter 1.7;

2. Front End: Custom HTML, JS, CSS;

3. DBMS: PostgreSQL 8.4;

4. Web Server: Apache; dan

5. Server: CentOS 5.5 (shared environtment).

SIKI menjadi tugas dan berada di bawah Bidang Informasi dan Pengembangan Sistem Kearsipan. SIKI adalah sistem informasi berbasis teknologi informasi yang digunakan untuk mengintegrasi data, memproses, menyimpan, dan mendistribusikan informasi arsip inaktif. SIKI merupakan sebuah sistem yang dirancang untuk mendorong terselenggaranya otomasi manajemen arsip inaktif di Arsip UGM yang kemudian dikembangkan dan digunakan di seluruh unit kerja di UGM. Program SIKI ini hanya dapat diakses oleh pengguna di lingkungan UGM, yaitu pimpinan unit pencipta arsip dan arsiparis atau pengelola arsip di unit kerja di lingkungan UGM yang berperan sebagai administrator. SIKI dibuat tahun 2014 dan sampai sekarang masih terus dikembangkan guna perbaikan lebih lanjut mengenai efektif dan efisien kerja SIKI. 
Tujuan dari pembuatan SIKI adalah kurangnya tingkat kesadaran unit kerja di lingkungan UGM dalam melakukan pengelolaan arsip inaktif secara efektif dan efisien, fungsi layanan penemuan kembali arsip, serta dalam kaitannya dengan kegiatan penyusutan arsip.

SIKI mempunyai alur kerja sebagai berikut:

1. Melakukan penataan arsip inaktif;

2. Input data arsip;

3. Daftar arsip inaktif;

4. Kalkulasi Jadwal Retensi Arsip (JRA);

5. Daftar usul musnah, daftar usul serah, daftar dinilai kembali;

6. Verifikasi; dan

7. Daftar musnah, daftar serah.

Alur kerja SIKI nomor 1 (satu) sampai dengan 5 (lima) merupakan alur kerja di fakultas atau unit kerja di lingkungan UGM. Alur kerja SIKI nomor 5 (lima) sampai dengan 7 (tujuh) merupakan alur kerja lanjutan di Arsip UGM.

Sampai dengan saat ini potret penggunaan SIKI di unit kerja di lingkungan UGM berdasarkan data monitoring records SIKI pada workshop tanggal 19-20 (sembilan belas sampai dengan dua puluh ) Oktober 2018 adalah sebagai berikut:

Berdasarkan hasil data monitoring records SIKI tersebut terdapat 11 (sebelas) unit kerja atau 33,3\% dari 33 (tiga puluh tiga) unit kerja yang belum pernah entry data arsip inaktif ke dalam SIKI. Sebanyak 19 (sembilan belas) unit kerja atau 57,6\% dari 33 (tiga puluh tiga) unit kerja yang telah entry data arsip inaktif kurang dari 100 (seratus) nomor arsip inaktif. Tiga unit

Tabel 2

Tabel Daftar Monitoring Records SIKI

\begin{tabular}{|c|c|c|}
\hline No. & Unit Kerja & $\begin{array}{l}\text { Jumlah } \\
\text { Records }\end{array}$ \\
\hline 1. & Fakultas Biologi & 1 \\
\hline 2. & $\begin{array}{l}\text { Fakultas Ekonomika } \\
\text { dan Bisnis }\end{array}$ & 2 \\
\hline 3. & Fakultas Farmasi & 25 \\
\hline 4. & Fakultas Filsafat & 2 \\
\hline 5. & Fakultas Geografi & 1 \\
\hline 6. & Fakultas Hukum & 0 \\
\hline 7. & Fakultas Ilmu Budaya & 0 \\
\hline 8. & $\begin{array}{l}\text { Fakultas Ilmu Sosial } \\
\text { dan Politik }\end{array}$ & 13 \\
\hline 9. & $\begin{array}{l}\text { Fakultas Kedokteran, } \\
\text { Kesehatan Masyarakat, } \\
\text { dan Keperawatan } \\
(\mathrm{KKMK})\end{array}$ & 68 \\
\hline 10 . & $\begin{array}{l}\text { Fakultas Kedokteran } \\
\text { Gigi }\end{array}$ & 2957 \\
\hline 11. & $\begin{array}{l}\text { Fakultas Kedokteran } \\
\text { Hewan }\end{array}$ & 25 \\
\hline 12. & Fakultas Kehutanan & 0 \\
\hline 13. & Fakultas MIPA & 10 \\
\hline 14. & Fakultas Pertanian & 9 \\
\hline 15. & Fakultas Peternakan & 431 \\
\hline 16. & Fakultas Psikologi & 0 \\
\hline 17. & Fakultas Teknik & 25 \\
\hline
\end{tabular}




\begin{tabular}{|c|c|c|}
\hline 18. & $\begin{array}{l}\text { Fakultas Teknologi } \\
\text { Pertanian }\end{array}$ & 52 \\
\hline 19. & Sekolah Pascasarjana & 21 \\
\hline 20. & Sekolah Vokasi & 0 \\
\hline 21. & Direktorat Aset & 30 \\
\hline 22. & $\begin{array}{l}\text { Direktorat } \\
\text { Kemahasiswaan }\end{array}$ & 0 \\
\hline 23. & Direktorat Keuangan & 12 \\
\hline 24. & $\begin{array}{l}\text { Direktorat Sumber } \\
\text { Daya Manusia (SDM) }\end{array}$ & 0 \\
\hline 25. & $\begin{array}{l}\text { Direktorat } \\
\text { Perencanaan }\end{array}$ & 0 \\
\hline 26. & $\begin{array}{l}\text { Direktorat Sistem dan } \\
\text { Sumber Daya } \\
\text { Informasi (DSSDI) }\end{array}$ & 15 \\
\hline 27. & UPT Perpustakaan & 0 \\
\hline 28. & $\begin{array}{l}\text { Rumah Sakit } \\
\text { Akademik (RSA) }\end{array}$ & 2 \\
\hline 29. & $\begin{array}{l}\text { Laboratorium } \\
\text { Penelitian dan } \\
\text { Pengujian Terpadu } \\
\text { (LPPT) }\end{array}$ & 10 \\
\hline 30. & $\begin{array}{l}\text { Tata Usaha dan } \\
\text { Rumah Tangga } \\
\text { (TURT) }\end{array}$ & 0 \\
\hline 31. & $\begin{array}{l}\text { Hukum dan } \\
\text { Organisasi (HUKOR) }\end{array}$ & 0 \\
\hline 32. & $\begin{array}{l}\text { Pusat Inovasi } \\
\text { Agroteknologi (PIAT) }\end{array}$ & 5 \\
\hline 33. & Arsip & 2544 \\
\hline
\end{tabular}

Sumber: Data Diolah, 2019

kerja atau 9,1\% dari 33 (tiga puluh tiga) unit kerja yang telah entry data arsip inaktif lebih dari 100 (seratus) nomor arsip inaktif. Data tersebut menjelaskan bahwa tingkat penggunaan SIKI masih rendah dan belum semua unit kerja di lingkungan UGM menggunakannya.

Penelitian ini memodifikasi teori yang mempengaruhi attitude toward using yaitu ignorance dan multidimensional committment. Berdasarkan model TAM sebelumnya, pengembangan model yang dilakukan oleh peneliti dapat dijabarkan sebagaimana ditampilkan dalam gambar 2.

\section{PEMBAHASAN}

Analisis deskriptif dalam penelitian ini bertujuan untuk mengetahui bagaimana tanggapan informan terhadap instrumen penelitian yaitu complexcity, power of distance, incentive fairness, identification, internalization, attitude toward using, dan intention to use.

\section{Instrumen Complexity}

Complexity atau kompleksitas didefinisikan sebagai sejauhmana pengguna mengharapkan teknologi menjadi bebas dari usaha. Tornatzky dan Klein (1982:28) menemukan bahwa semakin kompleks inovasi, semakin rendah tingkat penerimaan adopsi. Hal ini didukung oleh hasil penelitian Thompson et al. (1991:128) mengenai faktor yang mempengaruhi pemanfaatan teknologi atau hubungan antara complexity atau kompleksitas dan pemanfaatan teknologi adalah negatif. Berdasarkan hasil 


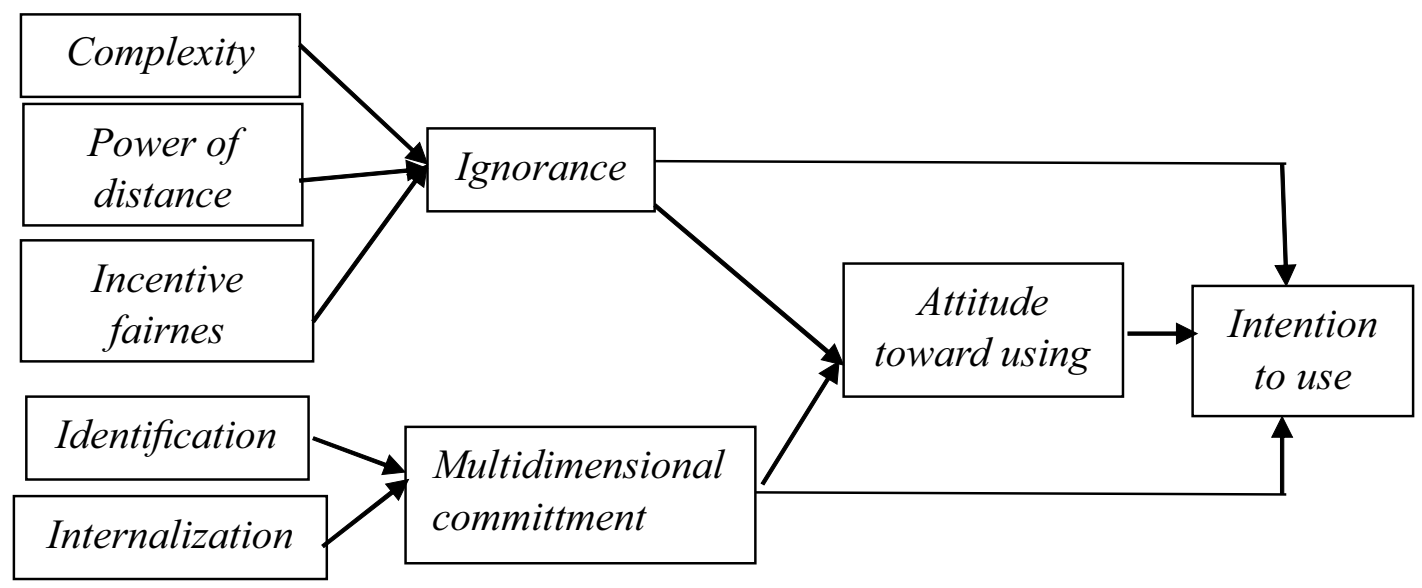

Gambar 2

Pengembangan Model Hubungan antar komponen dalam Technology Acceptance Model (TAM)

Sumber: Data diolah, 2019

wawancara terhadap sembilan key informan mengenai complexity pada bagian multiple path, ditemukan bahwa SIKI mudah dipelajari, mudah digunakan, mudah dimengerti, mudah dipahami serta tampilan SIKI yang jelas dan mudah dimengerti.

Complexity pada bagian multiple outcome berdasarkan hasil wawancara terhadap sembilan key informan

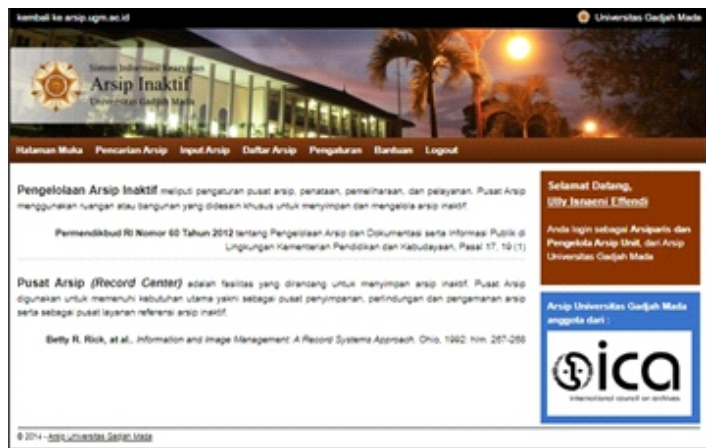

Gambar 3

Tampilan Sistem Informasi

Kearsipan Inaktif (SIKI)

Sumber: http://siki.arsip.ugm.ac.id/ ditemukan bahwa SIKI berguna untuk menyelesaikan tugas dan menemukan informasi yang diinginkan dengan cepat. Complexity pada bagian conflicting interdepence berdasarkan hasil wawancara terhadap sembilan key informan ditemukan bahwa SIKI ditampilkan dengan cara yang berguna

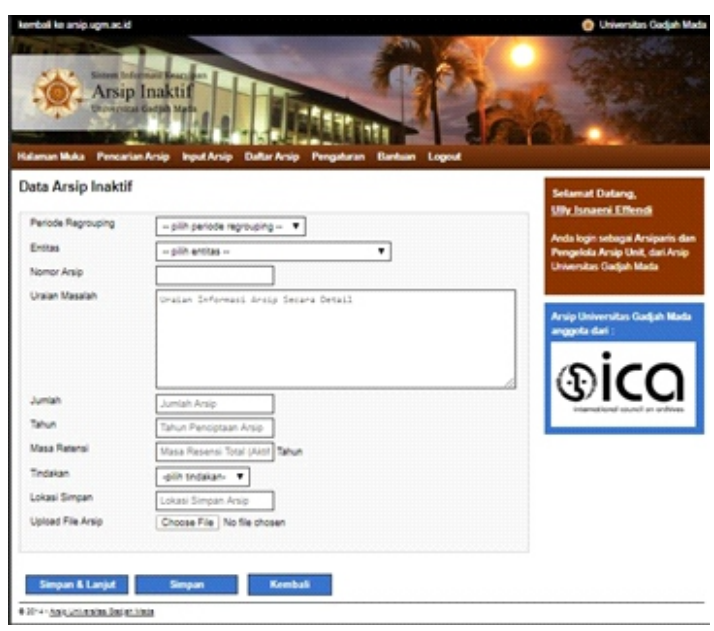

Gambar 4

Tampilan Sistem Informasi

Kearsipan Inaktif (SIKI)

Sumber: http://siki.arsip.ugm.ac.id/ 
dalam mencari informasi dan pemahaman input arsip dalam kaitannya dengan output daftar arsip inaktif. Complexity pada bagian probabilistic linkage berdasarkan hasil wawancara terhadap sembilan key informan ditemukan bahwa prosedur entry data pada SIKI saling berkaitan, efisien dalam prosedur penginputan, proses menjadi output jelas tidak ambigu, output jelas, dan output SIKI ini bermanfaat.

Berdasarkan studi di lapangan, ada empat karakteristik tugas utama yang dapat meningkatkan kompleksitas tugas seperti yang disampaikan oleh Campbell (1988:43) yaitu multiple paths, multiple outcome, conflicting interdepence, dan uncertain or probabilistic linkages, key informan. Karakteristik complexity atau kompleksitas dalam SIKI akan dapat diterima oleh key informan atau pengguna dalam hal ini administrator SIKI ketika memiliki kerumitan dan kompleksitas yang rendah. Melihat penjelasan di atas tampak bahwa tingkat kesulitan oleh key informan adalah rendah. Key informan memahami proses bisnis SIKI. Hal tersebut sejalan dengan penelitian Thompson et al. (1991:128) mengenai faktor yang mempengaruhi pemanfaatan teknologi yaitu hubungan antara kompleksitas dan pemanfaatan teknologi adalah negatif. Selain itu, hasil di lapangan sesuai dengan penelitian Igbaria et al. (1996:140) yang menemukan hubungan yang kuat antara kompleksitas yang dirasakan dan manfaat yang dirasakan dengan penggunaan. Kompleksitas tugas pencarian informasi adalah sebuah fitur dalam menentukan kinerja tugas atau ketidakpastian tentang tugas.

Dari sisi TAM, perceived ease of use atau persepsi kemudahan penggunaan menurut Davis (1989:320) merupakan tingkat kemudahan yang dirasakan seseorang dalam menggunakan teknologi. Sesuai dengan hasil penelitian, key informan merasakan kemudahan dalam menggunakan teknologi. Key informan merasakan kemudahan dan percaya dengan menggunakan sebuah sistem teknologi informasi akan memudahkan pekerjaannya. Dari sisi proses (input menghasilkan output) SIKI jelas dan kesesuaian dengan lingkungan pekerjaan. Hal tersebut hanya merupakan salah satu faktor keberhasilan sistem informasi saja. Faktor lainnya yang harus dipertimbangkan adalah pengguna mau menerima dan mau menggunakannya. Dari hasil penelitian, key informan selaku pengguna SIKI menerima kemudahan SIKI, namun dari sisi penggunaan, keputusan menggunakan SIKI terletak pada keputusan dan kewenangan pimpinan di fakultas atau unit kerja. Key informan hanya berperan sebagai pelaksana dari sebuah keputusan. Berbeda dengan pendapat Hartwick (1994:75) yang menyatakan bahwa partisipasi pengguna telah lama dianggap sebagai 
variabel kunci dalam pengembangan sistem informasi. Berdasarkan penelitian di lapangan partisipasi pengguna hanya salah satu variabel dalam pengembangan sistem informasi. Kemudahan pada SIKI tidak lantas membuat key informan sebagai administrator SIKI pada unit kerja secara langsung menggunakan sistem informasi tersebut tetapi ada faktor lain yang menjadi penentu penggunaan SIKI tersebut.

Studi ini menarik inferensi dari hasil wawancara terhadap key informan bahwa tingkat complexity dalam teknologi informasi SIKI rendah sehingga key informan merasakan kemudahan dalam menggunakan SIKI. Namun complexity yang rendah tersebut tidak dapat secara langsung menjadikan SIKI sebagai pilihan dalam penggunaan sistem teknologi informasi untuk pengelolaan arsip inaktif di unit kerja di UGM. Studi ini menggambarkan bahwa terdapat faktor lain yang mempengaruhi keputusan dalam penggunaan SIKI di unit kerja di UGM.

\section{Instrumen Power of Distance}

Power of distance yang dihadapi oleh key informan di unit kerja berhubungan dengan pimpinan secara langsung. Sesuai dengan power of distance dimensi budaya yang disampaikan oleh Hofstede (1980:80) yaitu merupakan tingkat kepercayaan atau penerimaan dari suatu power yang tidak seimbang, dimana perbedaan kekuasaan ini berbeda-beda tergantung dari tingkatan sosial, gender (jenis kelamin), ras, umur, tingkatan pendidikan, pencapaian, latar belakang, jabatan atau faktor lainnya. Tinggi rendahnya power of distance dipengaruhi oleh yang disampaikan oleh Hofstede (1980:80) tersebut.

Power of distance pada bagian pengaruh pimpinan, berdasarkan hasil wawancara dengan sembilan key informan ditemukan bahwa pimpinan dari enam key informan mendukung penggunaan SIKI dan mempunyai tanggapan yang bagus sementara itu tiga pimpinan key informan tidak mengetahui penggunaan SIKI di unit kerjanya karena key informan tidak memberikan informasi dan memberikan penjelasan keberadaan SIKI tersebut terhadap pimpinan key informan. Power of distance pada bagian wewenang berdasarkan hasil wawancara terhadap key informan adalah berkaitan dengan jawaban dari key informan mengenai pertanyaan power of distance pada bagian pengaruh pimpinan. Secara tidak langsung, dengan ada atau tidaknya pengaruh pimpinan seperti dukungan dan tanggapan terhadap penggunaan SIKI akan berakibat langsung terhadap pada jawaban wewenang seperti pendelegasian wewenang terkait SIKI dan besarnya wewenang terkait SIKI yang diberikan.

Studi ini menarik inferensi dari percakapan wawancara bahwa enam unit kerja memiliki tanggapan yang bagus 
terhadap SIKI. Meskipun tanggapan tersebut masih sebatas melihat SIKI sebagai sistem informasi atau sarana bantu memudahkan pekerjaan pengelolaan arsip inaktif di unit kerja. Dukungan dan tanggapan yang bagus terhadap penggunaan SIKI masih sebatas pada penggunaan sementara yang bersifat tidak resmi. Artinya adalah pimpinan memperbolehkan penggunaan SIKI tetapi belum ada tindakan atau keputusan yang jelas atau resmi. SIKI hanya digunakan pada bagian tertentu dalam suatu unit kerja. Sebagai contoh, berdasarkan wawancara terhadap key informan, SIKI hanya digunakan dimana key informan tersebut bertugas, padahal dalam suatu unit kerja terdapat banyak bagian-bagian unit kerja fakultas, fakultas mempunyai rektorat, departemen, program studi, unitunit departemen, unit pengembangan, dll. Semua unit tersebut mempunyai arsip inaktif. Pimpinan belum melihat SIKI sebagai suatu sistem yang terintegrasi seluruh unit kerja di UGM untuk pengelolaan arsip inaktif. Oleh karena itu dalam suatu unit kerja dibutuhkan kebijakan atau keputusan pimpinan terkait penggunaan SIKI secara resmi. Kebijakan atau keputusan penggunaan SIKI dapat berupa anjuran, surat resmi, edaran, pengumuman, instruksi maupun dengan sarana yang lainnya yang mempunyai kekuatan penggunaan SIKI.

\section{Instrumen Incentive Fairness}

Incentive fairness dipahami sebagai keadilan insentif yang Dessler (2005) mengisyaratakan bahwa insentif adalah tambahan balas jasa yang diberikan kepada karyawan tertentu atas prestasi produktivitas yang sesuai standar atau di atas standar. Tujuan utama dari insentif adalah alat motivasi dalam bekerja dan pendukung prinsip adil dalam pemberian kompensasi atas usahanya untuk mencapai tujuan organisasi. Incentive fairness di UGM termasuk dalam Insentif Berbasis Kinerja (IBK) yang mulai diterapkan pada tahun 2018. Pemberian IBK dimaksudkan untuk mengatasi banyaknya variasi skema pemberian insentif serta untuk mengurangi pendapatan yang lebar antar tenaga kependidikan, baik antar unit kerja maupun di dalam unit kerja sendiri.

Berdasarkan hasil wawancara, semua jawaban key informan mengarah kepada tidak adanya tambahan penghasilan khusus dari penggunaan SIKI yang diberikan oleh fakultas atau unit kerjanya. Namun demikian, semua key informan mendapatkan IBK dengan besaran yang berbeda-beda sesuai dengan ketentuan dan persyaratan yang ada. Semua key informan menjawab mendapat IBK karena termasuk pegawai di lingkungan UGM berdasarkan Peraturan Rektor Nomor 4 Tahun 2018 tentang 
Pemberian Insentif Berbasis Kinerja Pegawai di Lingkungan Universitas Gadjah Mada. Sistem insentif ini berlaku bagi seluruh unit kerja di UGM kecuali unit kerja yang masuk dalam kategori unit khusus. Perbedaannya adalah tidak semua key informan mengetahui apakah sebagai administrator SIKI ini mendapatkan insentif. Mengingat SIKI ini masih belum digunakan secara resmi pada unit kerja yang secara langsung belum menjadi tugas resmi bagi administrator SIKI. Studi ini menambahkan bahwa terdapat key informan yang mengerjakan SIKI ini sebagai pekerjaan sampiran atau pekerjaan tambahan yang tidak masuk dalam SKP. Padahal, IBK akan diberikan kepada tenaga kependidikan yang memenuhi ketentuan yaitu tidak melanggar etika dan kode etik pegawai UGM, tidak sedang menjalani hukuman disiplin, dan telah menyusun SKP target. Ketiga ketentuan tersebut apabila terpenuhi, tenaga kependidikan berhak mendapatkan insentif berbasis kinerja yang perhitungannya terdiri dari komponen aspek kedisiplinan dan aspek capaian kinerja. Oleh karena itu, studi ini memberikan gambaran kebijakan masa mendatang untuk penetapan regulasi yang baku atas penerapan SIKI. Di dalamnya, studi ini menyarakan penerapan SIKI ke dalam SKP beserta insentif bagi tenga kependidikan.

\section{Instrumen Identification}

Identification $\mathrm{dari} \mathrm{sisi}$ kemanfaatan SIKI atau perceived usefulness merupakan tingkat kepercayaan individu bahwa penggunaan teknologi ini akan meningkatkan kinerjanya (Venkatesh dan Davis, 2000:201). Perceived usefulness membentuk suatu kepercayaan untuk pengambilan keputusan untuk menggunakan atau tidak menggunakan sistem informasi tersebut. Davis (1989:331) menyatakan bahwa suatu sistem informasi dikatakan bermanfaat oleh penggunanya apabila mempunyai indikator mempercepat pekerjaan (work more quickly), meningkatkan performa (improve job performance), meningkatkan produktivitas (increase productivity), efektivitas (effectiveness), mempermudah pekerjaan (make job easier), dan bermanfaat. Faktor kemudahan yang menganggap dengan penggunaan sistem informasi akan mempermudah dalam penyelesaian pekerjaan apabila sistem informasi tersebut dapat digunakan dengan mudah.

Hasil wawancara terhadap key informan diperkuat dengan adanya faktorfaktor yang mempengaruhi anggapan kemudahan suatu sistem informasi yaitu mudah dipelajari (easy to learn), dapat dikontrol (controllable), jelas dan dapat dipahami (clear and understantable), 
fleksibel (flexible), mudah mahir (easy to become skillful), dan mudah digunakan (easy to use). Dari sisi TAM, perceived usefulness atau persepsi kegunaan, key informan percaya bahwa SIKI dapat meningkatkan prestasi kerjanya atau kinerjanya terkait dengan pengelolaan arsip inaktif. Salah satu contoh peningkatan kinerja key informan adalah key informan merasakan kecepatan dalam penemuan kembali arsip inaktif yang telah di entry ke dalam SIKI, output dari SIKI yang menghasilkan daftar arsip usul musnah, dan sebagainya yang memudahkan key informan dalam proses penyusutan arsip. Perceived usefulness atau persepsi kegunaan masih menurut Davis (1989:320) dipengaruhi oleh perceived ease of use atau persepsi kemudahan penggunaan karena semakin mudah sistem teknologi informasi digunakan maka semakin berguna dan bermanfaat sistem teknologi informasi tersebut dalam penyelesaian pekerjaan dan dapat meningkatkan kinerja pengguna, serta akan berpengaruh pada pengembangan sistem teknologi informasi.

Studi ini menarik inferensi berdasarkan wawancara terhadap key informan, bahwa proses identification ini terjadi ketika key informan mengadopsi sikap dan perilaku untuk mencapai kepuasan dan self-defining relationship dengan orang lain. Identification dianggap sebagai keyakinan dan penerimaan kepada organisasi, tercermin dalam perilaku seperti adanya kesamaan nilai dan tujuan pribadi dengan tujuan organisasi, penerimaan terhadap kebijakan organisasi serta adanya menjadi bagian dari organisasi. Artinya bahwa key informan sebagai administrator SIKI akan mematuhi kebijakan yang dibuat oleh organisasi. Kebijakan tersebut dapat berupa kebijakan penggunaan SIKI dalam pekerjaan manajemen kearsipan inaktif.

Studi ini mengidentifikasi bahwa key informan beranggapan bahwa dengan SIKI dapat menyelesaikan pekerjaan lebih cepat, meningkatkan produktivitas kerja, meningkatkan kinerja, dan meningkatkan efektivitas kerja. Hal tersebut sesuai dengan tujuan organisasi yang mengisyaratkan performance yang baik bahkan cenderung meningkat dari seluruh anggota organisasi, termasuk di dalamnya key informan sebagai administrator SIKI. Identification memberikan gambaran bahwa key informan merasakan peningkatan kinerja yang seharusnya dibarengi dengan kebijakan unit kerja dalam pengaplikasian SIKI ke depannya. Key informan membutuhkan kepastian dalam bentuk kebijakan penerapan SIKI.

\section{Instrumen Internalization}

Internalization atau internalisasi adalah upaya memasukan pengetahuan (knowing) dan keterampilan melaksanakan (doing) itu ke dalam diri. 
Perubahan sikap dan perilaku seseorang terjadi karena kesesuaian dengan apa yang dipercayai dan sesuai dengan sistem nilai yang dianutnya. Perubahan melalui proses internalisasi biasanya tidak mudah berubah selama nilai yang ada di dalam diri seseorang masih bertahan. (Kelman, 1958:53). Key informan sebagai administrastor SIKI dalam upayanya untuk mendapatkan pengetahuan tentang SIKI dilakukan dengan beberapa cara, seperti diskusi, bertanya, mencari tahu sendiri, sosialisasi, workshop, pelatihan, pendampingan, WhatsApp group dan lain sebagainya. Salah satu hal dalam proses internalisasi terkait dengan kelangsungan SIKI pada masing-masing unit kerja. Key informan menyatakan ingin menggunakan SIKI untuk ke depannya karena belum ada sistem informasi seperti (SIKI) ini. Salah satu key informan unit kerja menyatakan kelangsungan penggunaan SIKI dipengaruhi beberapa hal yang terkait dengan kebijakan SIKI. Kebijakan seperti peraturan Permenristekdikti Nomor 23 Tahun 2018 tentang JRA, Klasifikasi, Perka ANRI nomor 23 tahun 2017 tentang SKHK, jabatan arsiparis, dll.

Studi ini menarik inferensi dari hasil wawancara bahwa proses internalisasi yang dilakukan oleh key informan melalui tindakan praktek dengan kesadaran akan penggunaan SIKI dalam pekerjaannya khususnya pengelolaan arsip inaktif. Tindakan tersebut tanpa ada paksaan dari pihak lain yang akan membentuk kebiasaan dalam diri key informan. Berdasarkan studi di lapangan didapatkan hasil bahwa key informan telah melalui proses penghayatan, penugasan, penguasaan yang dilakukan secara mendalam oleh seseorang melalui pembinaan, penyuluhan, penataran, dan sebagainya. Key informan mendapatkan pembinaan melalui sosialisasi, pelatihan, workshop mengenai SIKI yang dilakukan oleh Arsip UGM selaku pemilik program SIKI dan pembina kearsipan di lingkungan UGM. Pembinaan tersebut berupa pemberian materi tentang SIKI dilanjutkan dengan praktek entry data arsip inaktif. Kegiatan pembinaan tersebut sebagai upaya memasukan pengetahuan (knowing) dan keterampilan melaksanakan (doing) itu ke dalam diri key informan. Dengan demikian, key informan akan menggunakan sistem tertentu dengan kesadaran sendiri tanpa ada paksaan.

Proses internalisasi key informan mengisyaratkan bahwa key informan mengetahui dengan pasti informasi, pengetahuan serta praktek dari SIKI tersebut. Key informan telah melalui proses memasukan pengetahuan (knowing) dan keterampilan melaksanakan (doing) itu ke dalam diri. Dari petikan wawancara didapatkan bahwa key informan secara sadar tanpa ada paksaan ingin menggunakan SIKI setelah mengetahui manfaat dari SIKI 
sebelumnya. Secara tidak langsung adalah SIKI ini memberikan manfaat bagi pekerjaan key informan.

\section{Instrumen Attitude Toward Using}

Attitude toward using dapat diartikan sebagai perasaan pengguna, baik positif maupun negatif untuk melakukan perilaku yang sudah ditentukan, dimana faktor sikap (attitude) sebagai salah satu aspek yang mempengaruhi perilaku individual. Key informan unit kerja pada dasarnya akan menggunakan sistem ini dengan alasan bahwa SIKI memberikan banyak manfaat dalam pekerjaan kearsipan. Proses penemuan kembali arsip inaktif yang lebih cepat menjadi salah satu alasan penggunaan SIKI ini. Studi ini menyajikan petikan percakapan wawancara sebagai berikut. SIKI pilihan yang bagus untuk arsip inaktif.

Studi ini menarik inferensi dari hasil wawancara terhadap key informan bahwa key informan menyadari bahwa SIKI ini berguna dan bermanfaat dalam kaitannya dengan pengelolaan arsip inaktif. Berdasarkan wawancara, key informan merasakan perasaan yang positif dari penggunaan SIKI. Perasaan positif tersebut mempengaruhi perilaku key informan. Selain itu, key informan mengakui bahwa sampai dengan saat ini di unit kerja masing-masing maupun di UGM itu sendiri belum mempunyai sistem informasi yang serupa, sehingga key informan menganggap SIKI ini merupakan pilihan yang bagus. Key informan menganggap menggunakan SIKI adalah hal yang menguntungkan dan menemukan kemudahan dalam menggunakan SIKI serta membantu dalam hubungannya dengan pekerjaan kearsipan khususnya arsip inaktif dari sejak entry data sampai dengan pencarian arsip inaktif. Melihat SIKI sebagai satusatunya sistem informasi untuk kearsipan inaktif di UGM, hendaknya menjadi pertimbangan tersendiri bagi pimpinan unit kerja dalam kaitannya dengan manajemen arsip inaktif.

\section{Instrumen Intention to Use}

Intention to use merupakan minat (keinginan) seseorang secara sadar untuk melakukan atau tidak melakukan suatu perilaku di waktu yang akan datang yang telah ditentukan sebelumnya. Pada instrument ini jawaban key informan mengarah pada keinginan key informan untuk menggunakan SIKI karena manfaat yang dirasakan dan kemudahan dalam penggunaan SIKI, namun demikian keinginan tersebut belum dapat terwujud karena berhubungan dengan kebijakan penggunaan SIKI, jaminan keamanan data, belum tertatanya arsip inaktif, dll. Minat untuk melakukan suatu perilaku tertentu dalam hal ini perilaku akan menggunakan SIKI didasari dari adanya ketentuan atau alasan tertentu. Key informan mensyaratkan seperti keputusan pimpinan mengenai penggunaan SIKI di 
unit kerjanya menjadi dasar penggunaan SIKI selanjutnya, meskipun key informan merasa menggunakan SIKI itu mudah dengan berbagai kelebihan dan manfaat, key informan mengetahui fungsi SIKI sebagai bagian dari manajemen arsip inaktif, sarana finding aids atau penemuan kembali arsip inaktif, dan sarana bantu penyusutan arsip.

Kondisi penerimaan SIKI di unit kerja, berdasarkan hasil wawancara peneliti dengan key informan dan pengamatan langsung di lapangan, jumlah administrator SIKI yang terdaftar di Arsip UGM sampai dengan pada saat penelitian ini dilakukan adalah sebanyak 35 unit kerja.

Tabel 3

Daftar Administrator SIKI di Lingkungan UGM

\begin{tabular}{|c|l|}
\hline No. & \multicolumn{1}{|c|}{ Unit Kerja } \\
\hline 1. & Fakultas Biologi \\
\hline 2. & Fakultas Ekonomika dan Bisnis \\
\hline 3. & Fakultas Farmasi \\
\hline 4. & Fakultas Filsafat \\
\hline 5. & Fakultas Geografi \\
\hline 6. & Fakultas Hukum \\
\hline 7. & Fakultas Ilmu Budaya \\
\hline 8. & Fakultas Ilmu Sosial dan Politik \\
\hline 9. & $\begin{array}{l}\text { Fakultas Kedokteran, Kesehatan } \\
\text { Masyarakat, dan Keperawatan } \\
\text { (KKMK) }\end{array}$ \\
\hline 10. & Fakultas Kedokteran Gigi \\
\hline 11. & Fakultas Kedokteran Hewan \\
\hline 12. & Fakultas Kehutanan \\
\hline 13. & Fakultas MIPA \\
\hline 14. & Fakultas Pertanian \\
\hline 15. & Fakultas Peternakan \\
\hline 16. & Fakultas Psikologi \\
\hline 17. & Fakultas Teknik \\
\hline
\end{tabular}

\begin{tabular}{|c|l|}
\hline 18. & Fakultas Teknologi Pertanian \\
\hline 19. & Sekolah Pascasarjana \\
\hline 20. & Sekolah Vokasi \\
\hline 21. & Direktorat Aset \\
\hline 22. & Direktorat Kemahasiswaan \\
\hline 23. & Direktorat Keuangan \\
\hline 24. & $\begin{array}{l}\text { Direktorat Sumber Daya } \\
\text { Manusia (SDM) }\end{array}$ \\
\hline 25. & Direktorat Perencanaan \\
\hline 26. & $\begin{array}{l}\text { Direktorat Sistem dan Sumber } \\
\text { Daya Informasi (DSSDI) }\end{array}$ \\
\hline 27. & UPT Perpustakaan \\
\hline 28. & Rumah Sakit Akademik (RSA) \\
\hline 29. & $\begin{array}{l}\text { Laboratorium Penelitian dan } \\
\text { Pengujian Terpadu (LPPT) }\end{array}$ \\
\hline 30. & $\begin{array}{l}\text { Tata Usaha dan Rumah Tangga } \\
\text { (TURT) }\end{array}$ \\
\hline 31. & $\begin{array}{l}\text { Hukum dan } \\
\text { (HUKOR) }\end{array}$ \\
\hline 32. & $\begin{array}{l}\text { Pusat Inovasi Agroteknologi } \\
\text { (PIAT) }\end{array}$ \\
\hline 33. & Badan Penerbit \\
\hline 34. & $\begin{array}{l}\text { Keamanan dan Keselamatan } \\
\text { Kampus }\end{array}$ \\
\hline 35. & Arsip \\
\hline
\end{tabular}

Sumber: Data diolah, 2019

Administrator SIKI tersebut mendapat username dan password dari administrator SIKI pusat di Arsip UGM. Administrator SIKI unit kerja diberikan kewenangan dan tanggung jawab sebagai administrator SIKI unit kerjanya. Jumlah tersebut masih kurang dibandingkan dengan jumlah fakultas, sekolah, direktorat, dan pusat studi di lingkungan UGM. Mengingat semua itu termasuk unit kerja di lingkungan UGM yang menghasilkan arsip inaktif. Username dan password SIKI tersebut menjadi pintu masuk penggunaan SIKI bagi unit kerja. 
Bagi unit kerja yang tidak mempunyai username dan password SIKI otomatis tidak dapat menggunakan SIKI. Hal tersebut berimplikasi kepada tersosialisasinya SIKI di unit kerja di lingkungan UGM.

Terbatas pada unit kerja yang diteliti, SIKI mudah dipelajari dan digunakan. Administrator SIKI menemukan bahwa fitur-fitur yang terdapat dalam SIKI mudah dipahami karena menggunakan bahasa yang mudah dimengerti. Administrator SIKI telah terbiasa dengan bahasa yang digunakan dalam SIKI. Studi di lapangan menemukan bahwa tidak semua unit kerja menggunakan SIKI secara terus menerus. Artinya adalah administrator SIKI mempunyai pekerjaan lain disamping sebagai administrator SIKI dan dimungkinkan SIKI bukan merupakan tugas pokok atau utama. Disamping fiturfitur dan bahasa SIKI yang mudah dipahami oleh administrator SIKI, terdapat saran dan masukan yang disampaikan oleh administrator SIKI terkait dengan tampilan SIKI secara umum. Saran dan masukan dari key informan seperti fitur atau menu yang berisi panduan atau pedoman SIKI, menu edit dan hapus, excel dapat diedit, tampilan, proses input dengan import excel/spreadsheet dapat dikembangkan.

Tingkat penerimaan teknologi setiap individu berbeda-beda. Persepsi mengenai teknologi berawal dari proses kognitif dan keyakinan mengenai teknologi. Hasil wawancara terhadap key informan atau administrator SIKI didapatkan bahwa terdapat faktor yang menyebabkan unit kerja belum sepenuhnya menerima, menggunakan, dan memanfaatkan SIKI. Faktor yang pertama adalah kebijakan pimpinan unit kerja yang belum secara resmi mewajibkan penggunaan SIKI di unit kerjanya. Adanya kebijakan masingmasing unit kerja dalam keputusan pemilihan penggunaan sistem informasi terkait dengan kegiatan kearsipannya. Tiga dari sembilan key informan menyatakan bahwa di unit kerjanya sampai dengan saat ini sudah menggunakan sistem informasi sendiri terkait dengan pengelolaan arsip. Sistem informasi tersebut dibuat oleh intern unit kerja itu sendiri disesuaikan dengan kebutuhan masing-masing unit kerja. Sistem informasi yang digunakan di unit kerja tersebut lebih kepada manajemen arsip aktif. Sistem informasi digunakan untuk tata persuratan, akses penomoran surat, agenda surat, d1l. untuk memudahkan manajemen arsip aktif secara internal di unit kerja masingmasing. Output yang dihasilkan dari sistem informasi tersebut selanjutnya digunakan sebagai bahan tindak lanjut pengelolaan arsip inaktif. Penggunaan sistem informasi di unit kerja tersebut 
berawal dari masalah dan kebutuhan. Penomoran surat keluar yang berurutan, tersimpannya data surat masuk maupun surat keluar, dan kemudahan dalam pencarian arsip menjadi alasan pembuatan sistem informasi di unit kerja.

Hasil wawancara dan pengamatan di lapangan, unit kerja yang telah melakukan penataan arsip inaktif sesuai dengan kaidah kearsipan akan lebih mudah dalam pelaksanaan entry data arsip inaktif ke SIKI. Hal ini sesuai dengan alur kerja SIKI yaitu dimulai dengan tahapan melakukan penataan arsip inaktif, input data arsip, daftar arsip inaktif, kalkulasi Jadwal Retensi Arsip (JRA), daftar usul musnah, daftar usul serah, daftar dinilai kembali, verifikasi, dan daftar musnah dan daftar serah. Tahapan pertama yaitu melakukan penataan arsip inaktif telah dilakukan oleh beberapa key informan. Data dari key informan didapatkan jumlah entry data arsip inaktif yaitu KI 1 (23), KI 2 (35), KI 3 (500), KI 4 (10), KI 5 (400), KI 6 (25), KI 7 (11), KI 8 (2), dan KI 9 (2544). Key informan atau KI dengan jumlah entry data arsip inaktif yang sangat tinggi, KI 3, KI 5, dan KI 9, merupakan administrator SIKI yang telah entry data arsip inaktif sejak awal SIKI diperkenalkan dan sebagai unit kerja yang menjadi target uji coba SIKI. Awal mulai entry data mengakibatkan perbedaan jumlah entry data arsip inaktif unit kerja. Disamping itu, administrator SIKI tersebut mempunyai job description sebagai pengelola arsip maupun arsiparis baik arsiparis Pegawai Negeri Sipil (PNS) maupun arsiparis versi UGM, dimana tugas pokoknya adalah bidang kearsipan termasuk didalamnya adalah pengelolaan arsip inaktif di unit kerjanya. Sehingga administrator SIKI dapat fokus ke pekerjaan bidang kearsipan, namun apabila diberi pekerjaan tambahan lainnya porsinya lebih sedikit dibandingkan dengan pekerjaan pokoknya. Lain halnya dengan administrator SIKI KI 1, KI 2, KI 4, KI 6, KI 7 , dan KI 8 meskipun ada administrator SIKI petugas arsip, tetapi di lapangan yang bersangkutan mempunyai tugas di luar bidang kearsipan.

Berdasarkan beberapa temuan penelitian tampak bahwa keinginan menggunakan SIKI tidak hanya dipengaruhi oleh kemudahan dan manfaat dari teknologi sistem informasi itu sendiri tetapi ada faktor lain yaitu kebijakan penggunaan SIKI. Kebijakan tersebut sangat mempengaruhi penggunaan SIKI karena menyangkut suatu keputusan yang akan berakibat dalam pekerjaan seharihari. Namun hal tersebut belum sepenuhnya menjadi alasan untuk menggunakan lebih lanjut. Meskipun administrator SIKI merasakan manfaat dari penggunaan SIKI dalam mendukung pekerjaan kearsipan sehari-hari, khususnya untuk arsip inaktif, namun terdapat faktor lain yang lebih 
berpengaruh terhadap pengaplikasian SIKI tersebut, yaitu kebijakan penggunaan SIKI.

Selain itu peraturan pemerintah yang terkait dengan fitur yang terdapat dalam SIKI seperti pada fitur entitas yang berhubungan dengan klasifikasi arsip dan fitur masa retensi arsip yang berhubungan dengan Jadwal Retensi Arsip yang baru saja disahkan dengan Permenristekdikti Nomor 23 Tahun 2018 tentang Klasifikasi Arsip, Jadwal Retensi Arsip, dan Sistem Klasifikasi Keamanan dan Akses Arsip Dinamis di Lingkungan Kementrian Riset, Teknologi, dan Pendidikan Tinggi yang diikuti dengan peraturan rektor UGM. Khusus bagi arsiparis, fitur daftar yang terdapat dalam SIKI erat kaitannya dengan pelaporan kegiatan kearsipan yang disesuaikan dengan kebutuhan arsiparis disesuaikan dengan Peraturan Kepala Arsip Nasional Republik Indonesia Nomor 5 Tahun 2016 tentang Standar Kualitas Hasil Kerja Pejabat Fungsional Arsiparis. Sehingga SIKI menjadi efektif dan efisien. Perkembangan-perkembangan yang terjadi yang berkaitan dengan SIKI seharusnya di sesuaikan sehingga hasilnya sesuai dengan ketentuan yang berlaku dan tidak dua kali kerja.

Dari sisi key informan sebagai administrator SIKI, administrator SIKI perlu dilakukan evaluasi pegawai yang berhak menjadi administrator SIKI bagi masing-masing unit kerja. Selanjutnya adalah tidak setiap unit kerja di lingkungan UGM mempunyai pengelola arsip, petugas arsip, maupun arsiparis sendiri yang mempunyai job description mengelola arsip inaktif unit kerja. Volume arsip inaktif masing-masing unit kerja dapat dilihat dari struktur organisasinya. Sebagai contoh adalah unit kerja fakultas. Fakultas mempunyai dekanat atau tata usaha kantor pusat fakultas, program studi, departemen, laboratorium, dll yang semuanya dapat menghasilkan arsip. Volume arsip yang besar tidak dibarengi dengan jumlah pengelola arsip, petugas arsip, maupun arsiparis, sehingga pekerjaan kearsipan hanya disampirkan atau ditambahkan kepada staf, bukan sebagai pekerjaan pokok atau utama. Atau sebaliknya jabatan pengelola arsip, petugas arsip, maupun arsiparis dalam SKP tetapi "disampiri" atau diberikan tugas tambahan yang jumlahnya melebihi pekerjaan pokok atau utamanya sebagai pengelola arsip, petugas arsip, maupun arsiparis.

Selain itu, pada penelitian ini didapatkan kenyataan di lapangan bahwa tidak hanya lima external variabels yang telah dipaparkan di atas yang dapat mempengaruhi attitude toward using yang nantinya akan menjadi intention of use. Terdapat faktor lain yang mempengaruhi yaitu salah satunya adalah kebijakan penggunaan SIKI tersebut. 


\section{KESIMPULAN}

Berdasarkan hasil penelitian terdapat beberapa temuan penelitian yang diperoleh, yaitu SIKI mudah dipelajari dan digunakan oleh administrator SIKI, kadilan insentif bagi administrator SIKI belum tercapai, SIKI bermanfaat untuk pengelolaan arsip inaktif, penemuan kembali arsip inaktif, dan penyusutan arsip, administrator SIKI tertarik menggunakan SIKI dalam pekerjaan kearsipan inaktif. Dari sisi manajerial, faktor job description administrator SIKI mempengaruhi penggunaan SIKI, SIKI dapat menjadi pekerjaan pokok (utama) atau hanya menjadi pekerjaan tambahan berdasarkan faktor job description yang diberikan, tidak setiap unit kerja di lingkungan UGM mempunyai pengelola arsip, petugas arsip, maupun arsiparis yang mempunyai job description utama mengelola arsip inaktif, terdapat peluang kelanjutan sistem informasi SIKI ini karena dinilai oleh pengguna dapat memberikan manfaat, dan sistem informasi sejenis belum pernah dimiliki oleh UGM.

Berdasarkan hasil analisis data penelitian dan teori-teori yang dijadikan sebagai landasan dan pembahasan penelitian ini, saran yang dapat direkomendasikan adalah untuk penelitian selanjutnya, pimpinan pengambil kebijakan, pengelola arsip di unit kerja, dan Arsip UGM. Bagi penelitian berikutnya diharapkan dapat menambah external variabels lainnya yang mempengaruhi penerimaan sistem informasi SIKI. Kedepan sebaiknya dilakukan penelitian yang dapat melihat perkembangan dan perubahan kebutuhan serta perilaku pengguna terhadap perubahan SIKI. Saran bagi pimpinan pengambil kebijakan adalah perlunya kebijakan strategik atau kejelasan penetapan penggunaan SIKI di seluruh unit kerja di lingkungan UGM. Wujud kebijakannya adalah ketetapan bahwa SIKI sebagai manadatory procedures di setiap unit. SIKI masih menjadi rekomendasi bagi sistem informasi arsip inaktif di lingkungan UGM sehingga perlu untuk segera ditindaklanjuti. Rekomendasi ini berdasarkan kemanfaatan masa mendatang sebagai bahan pengambilan keputusan. Sedangkan bagi pengelola arsip di unit kerja adalah pengelolaan arsip inaktif harus segera dilaksanakan di unit kerja sesuai dengan kaidah kearsipan. Tugas sebagai administrator SIKI masuk ke dalam SKP dan menjadi dasar penilaian IBK. Bagi Arsip UGM adalah SIKI dikembangkan sesuai dengan kebutuhan dan perkembangan jaman, up dating kebijakan dan peraturan perundang-undangan yang terkait dengan instrumen pada SIKI, sosialisasi SIKI tidak terbatas pada administrator SIKI saja tetapi pada level pimpinan sebagai pengambil kebijakan, 
pelatihan lanjutan bagi administrator SIKI perlu dilakukan lagi, serta pertemuan berkala sebagai bentuk dari evaluasi rutin bagi administrator SIKI.

\section{DAFTAR PUSTAKA}

\section{Sumber Bahan Pustaka}

Cambell, Donald J. (1988). Task Complexity: A Review and Analysis. Academy of Management Review, 13(1), 4052.

Creswell, John W. (2009). Research Design: Qualitative, Quantitative and Mixed Methods Approaches. L o s A nge 1 e s: S A G E Publications.

Davis, F.D. (1989). Perceived Usefulness, Perceived Ease of Use and User Acceptance of Information Technology. MIS Quarterly, 13(3), 319-340.

Davis, F.D. (1986). A technology acceptance model for empirically testing new end user information systems: theory and results," Doctoral dissertation, Sloan School of Management, Massachusetts Institute of Technology. Davis, F.D, Bagozzi. R.P. \& Warshaw. P.R. (1989). User acceptance of computer technology: a comparison of two theoretical models, Management Science, 35, 982-1003.

Dessler, Gary. (2005). Human Resources Management $\left(10^{\text {th }} \mathrm{Ed}\right)$. Upper Saddle River: Pearson Education Inc.
Hartwick, Jon, Barki, Henri. (1994). $\mathrm{M}$ e a s u ring $\mathrm{U}$ s e $\mathrm{r}$ Participation,User Involvement, and User Attitude. MIS Quarterly, 18(1), 59-82.

Hofstede, Geert. (1980). Culture's Consequences: International Differences In Work Related Values. Beverly Hills: SAGE Publication.

Igbaria, M., Parasuraman, S. Baroudi, J. (1996). A Motivational Model of Microcomputer Usage. Journal of Management Information Systems, 13(2), 127-143.

Kelman, Herbert C (1958). Compliance, I d e n t i fi c a t i o n, a n d Internalization Three Processes of Attitude Change. Journal of Conflict Resolution, 2(1), 51-60.

Maher, William J. (1992). The Management of College and University Archives. London: Scarecrow Press.

Meyer, J.P., Allen, N.J. (1991). A ThreeComponent Conceptualization of Organizational Commitment. Human Resource Management Review, 1(1), 61-89.

Miles, M.B., Huberman, A.M. (1994). Qualitative Data Analysis (2 ${ }^{\text {nd }}$ ed). California: SAGE Publication.

McLeod, Raymond, Schell, George P. ( 20008$)$. Management Information System $\left(10^{\text {th }} \mathrm{ed}\right)$. Upper Saddle River: Prentice Hall.

Mowday, R.T., Porter, L.W., \& Steers, 
R.M. (1982). EmployeeOrganization Linkages: The Psychology of Commitment, Absenteeism, and Turnover. New York: Academic Press.

Nottelmann, Nikolaj. (2015). The Cambridge Dictionary of Philosophy $\left(3^{\text {rd }}\right.$ ed). New York: Cambridge University Press.

O'Brien, James A. (2005). Introduction to Information Systems. New York: McGraw-Hill.

Pitt, L., Berthon, P., Watson, R. (1996). From Surfer To Buyer on The W W W : What Marketing Managers Might Want to Know. Journal of General Management, 22(1): 1-13.

Rogers, E.M., Shoemaker, F.F. (1971). Communication of Innovations: A Cross-Cultural Approach. New York: Free Press.

Sun, Heshan, Zhang, Ping. (2006). The Role Moderating Factors in User Technology Acceptance. International Journal HumanComputer Studies, 64, 53-78.

Steers, R. M., \& Porter, L. W. (1983). Motivation and Work Behavior. Edisi Ke-3. New York: McGraw Hill Book Company.

Straub, D., Limayem, M, Karahanna, E. (1995). Measuring System Usage: Implication for IS Theory Testing. Management Science, 41(8), 1328-1342.

Thompson, R.L., Howell, Jane M., Higgins, Cristopher A. (1991). Personal Computing: Toward A
Conceptual Model of Utilization. Management Information System Quarterly, 15(1), 125143.

Tornatzky, L.G., Klein, K.J. (1982). Innovation Characteristics and Innovation Adoption Implementation: A MetaAnalysis of Findings. IEEE Transactions on Engineering Management, 29(1), 28-45.

\section{Sumber Produk Hukum}

Undang-Undang Republik Indonesia Nomor 43 Tahun 2009. Kearsipan. Jakarta.

Peraturan Kementrian Riset dan Teknologi Nomor 23 Tahun 2018 . Klasifikasi Arsip Klasifikasi Arsip, Jadwal Retensi Arsip, dan Sistem Klasifikasi Keamanan dan Akses Arsip.

Peraturan Kepala Arsip Nasional Republik Indonesia Nomor 5 Tahun 2016. Standar Kualitas Hasil Kerja Pejabat Fungsional Arsiparis.

Peraturan Rektor Nomor 1 Tahun 2015. Kedudukan, Fungsi, dan Tugas Organisasi di Lingkungan Universitas Gadjah Mada. Yogyakarta.

Peraturan Rektor Nomor 4 Tahun 2018. Pemberian Insentif Berbasis Kinerja Pegawai di Lingkungan Universitas Gadjah Mada. Yogyakarta.

Peraturan Rektor Nomor 2 Tahun 2019. Penyusutan Arsip di Lingkungan Universitas Gadjah Mada. Yogyakarta. 